\title{
Environmental Impact Assessment (EIA); A useful tool to address climate change in Ghana
}

\author{
Emmanuel Amankwah \\ Agricultural Engineering Dept. Wa Polytechnic, P. O. Box 553, Wa, Upper West Region, Ghana
}

Email address:

trustee7a@yahoo.com

\section{To cite this article:}

Emmanuel Amankwah. Environmental Impact Assessment (EIA); A Useful Tool to Address Climate Change in Ghana. International Journal of Environmental Protection and Policy. Vol. 1, No. 4, 2013, pp. 94-100. doi: 10.11648/j.ijepp.20130104.18

\begin{abstract}
The Environmental Protection Agency (EPA) since its inception in 1994 has been responsible for the implementation of Environmental Impact Assessment (EIA) regulation in Ghana. Many EIA have been performed on major projects such as mining, dams, gas projects but much has not been done in the mitigation of $\mathrm{Carbon}^{\mathrm{Dioxide}}\left(\mathrm{CO}_{2}\right)$ emissions which is said to be the main driving force of climate change. This reviewed paper therefore proposes the extension of the EIA regulations to small projects or activities such as deforestation, extensive land clearing, small scale mining and emissions from vehicles that have the potential of influencing climate change. The research was carried out by an extensive review of literature, reports, interaction with opinion leaders, lecturers, colleagues and students. The paper has attempted to explain the use of EIA in addressing the numerous environmental challenges by outlining the effect of climate change, EIA procedure in Ghana, the role of EIA in addressing climate change especially the emission of $\mathrm{CO}_{2}$. It was also established that the principle of EIA could be used to regulate pollution abatement, wastes management, conservation of natural resources, proper agricultural practices, development of clean and efficient energy sources. This application of EIA in climate change mitigation will safeguard the environment and improve the standard of living of the people. The paper concludes with some suggested recommendations.
\end{abstract}

Keywords: EIA, Climate Change, EPA, $\mathrm{CO}_{2}$ Emission, Environment

\section{Introduction}

Climate Change has become a global phenomenon which has received serious attention internationally in recent years. The climate is basically the average weather conditions of a particular vicinity observed over a period of time. According to the International Panel for Climate Change (IPCC), climate change refers to any change in climate over time, whether due to natural variability or as a result of human activities. The United Nations Framework Convention on Climate Change (UNFCCC) also defines it as a change of climate that is attributed directly or indirectly to human activities that alter the composition of the global atmosphere and in addition to natural climate variability observed over comparable time periods (in decades). This change according to many researchers is as a result of human activities such as extensive use of fossil fuels, industrial emissions, production of cement, deforestation, and land degradation through land use and land use cover change, which release Green House Gases (GHGs) into the atmosphere. There have been several publications pointing to the fact that anthropogenic activities have been responsible for the rising levels of $\mathrm{CO}_{2}$ in the atmosphere and this therefore calls for a paradigm shift. According to Prentice et al. (2001) several lines of evidence confirm that the additional $\mathrm{CO}_{2}$ that has accumulated in the atmosphere since the beginning of the industrial revolution is almost entirely caused by human activities. IPCC (2007) report also confirms that there is $90 \%$ likelihood of human activities being the major cause of the warming of the climate system which causes this change even though EI Nińo and La Nińa as well as volcanic eruptions can influence the climate in certain times of the year. The surface air temperature according to IPPC (2007) has increased by about $0.7^{\circ} \mathrm{C}$ across the globe over the preindustrial temperatures which the World Bank report also put at $0.8{ }^{\circ} \mathrm{C}$ with ocean temperatures rising by $0.09{ }^{\circ} \mathrm{C}$ World Bank (2012) thus there is an indisputable evidence of global warming. Zhang et al. (2007) also revealed that there are numerous evidences of anthropogenic activities that primarily influence climate change based on research over the past decades. 
If human activities are mainly responsible for climate change which is becoming a threat to human society then there is the need to consider a paradigm shift from the current way of doing things irrespective of the level of the country's development. It is true that there are challenges by the international bodies to reach a consensus as to the certainty of global warming or climate change; nevertheless, putting up preventive measures to safe-guard any eventuality will be the best thing to do. Any divisive stand is rather going to compromise the actions needed to be taken to arrest the impact of climate change and the poor nations are the most vulnerable. The Copenhagen Accord is to hold the temperature rise less than $2{ }^{\circ} \mathrm{C}$ by the end of the century and each country is expected to reduce its GHG emissions (Perlmutter and Rothstein, 2011). Already a temperature rise beyond the $2{ }^{\circ} \mathrm{C}$ is possible and it's being predicted that there is likely to be a temperature rise of $4{ }^{\circ} \mathrm{C}$ by the close of the century (World Bank, 2012). Dr. Jim Yong Kim, President, World Bank Group said that the $4^{\circ} \mathrm{C}$ scenarios will be devastating which will cause the inundation of coastal cities; increase risks for food production potentially leading to higher malnutrition rates with many dry regions becoming dryer and wet regions wetter; unprecedented heat waves in many regions, especially in the tropics and substantially exacerbated water scarcity in many regions; increased frequency of highintensity tropical cyclones; and irreversible loss of biodiversity, including coral reef systems (ibid).

The conduct of Environmental Impact Assessment (EIA) is therefore one of the key ways to ensure that a temperature rise below $2{ }^{\circ} \mathrm{C}$ is maintained. EIA is a comprehensive project management tool to collect, analyze and evaluate environmental effects of a proposed undertaken. Normally, EIA is conducted on major projects such as hydro dams, mining and road construction which are likely to have negative impact on the environment but does not incorporate climate change impacts; however, there are quite a number of small projects such as agricultural land clearing, misapplication of chemical fertilizers and pesticides which may have serious environmental implications. The use of EIA to incorporate climate change resilience and regulate every undertaken that has the potential of releasing $\mathrm{CO}_{2}$ and other GHGs will therefore be a step in the right direction to reduce GHG emissions. Article 4 (f) of UNFCCC (1992) and a number of articles of the Kyoto Protocol (1997) clearly emphasize on the need to lower the adverse effects of climate change by minimizing the emission of GHGs and promote adaptation or mitigation responses to projects that has influence on climate change thus the use of EIA to help address the impact of climate change cannot be overemphasized.

\subsection{Climate Change Scenario in Ghana}

In Ghana, the Second National Communication report to UNFCCC indicated that the national GHG emissions including land use and land use cover change has increased steadily from $-16.8 \mathrm{MtCO}_{2} \mathrm{e}$ in 1990 to $12.2 \mathrm{MtCO}_{2} \mathrm{e}$ in 2002 and further $23.9 \mathrm{MtCO}_{2} \mathrm{e}$ in 2006 . Available information gathered through field work, literature, books, and reports among others point to the fact that Ghana is experiencing climate variation in recent times. Studies have shown that most farmers have observed warmer temperatures and reduction of rainfall figures over the past decades (Gbetibouo, 2008; Deressa et al., 2011) which is a sign of climate variation and this sometimes results in crop failure leaving farmers in serious indebtedness, low incomes and poverty. Research conducted by the Friedrick Ebert Stiftung (FES) across the country with about 3000 respondents also confirms rising temperatures and decline rainfall. The analysis of climate data from 1961-2010 from five synopsis stations in the three northern regions of Ghana clearly indicates rising temperatures and declining rainfall.

Analysis of the Normalized Difference Vegetative Index (NDVI) of satellite data in 1986, 1991 and 2000 for land cover and land cover use trend in the Upper West Region using ERDAS Imagine 9.3 shows a reduction in vegetative cover through deforestation and resettlement in the region. Similar research across the nation from 2000-2008 also shows a massive decline in forest cover through logging, deforestation and resettlement among others. These are serious threat to climate change since deforestation is one of the main factors that cause climate change as indicated by (Zeng, 2003; Prospero and Lamb, 2003; IPCC, 2007). Anthropogenic activities and agricultural expansion in most populated part of Ghana has also resulted in vegetation degradation (Agyepong et al., 1999). According to the Global Facility for Disaster Reduction and Recovery (GFDRR, 2012), Ghana is ranked high among African countries most exposed to climate related risks such as floods, droughts, coastal erosion, pest infestation, urban hazards and landslides especially in the 3 northern regions of Ghana.

A survey conducted among cocoa farmers in the south of Ghana also affirmed rising temperatures and declining rainfall as an indication of climate change which is becoming a threat to the cocoa industry in Ghana. A research conducted using the General Circulation Models (GCM) in conjunction with Simple Climate Models (SCM) in the cocoa growing areas indicated that projected mean annual rainfall values in the semi deciduous forest zone of Ghana will decline by $-2.8,-10.9$ and $-18.6 \%$ in 2020,2050 and 2080 respectively while the evergreen rainforest zone, mean annual rainfall will also decline by $-3.1,-12.1$ and $20.2 \%$ respectively in the same periods. Mean annual temperature changes will rise by $0.8,2.5$ and 5.4 and 0.6 , 2.0 and $3.9{ }^{\circ} \mathrm{C}$ in the semi deciduous and evergreen rainforest zones in 2020, 2050 and 2080 respectively (Anim-Kwapong and Frimpong, 2006). Truly, several research works have confirmed that the climate in Ghana is changing and this may be as results of the use of fossil fuels, deforestation and bush burning among others. 


\subsection{Climate Change and its Challenges}

Boko et al. (2007) stated that climate change and climate variability are likely to compromise many Africa countries' effort to ensure agricultural productivity and food security. The report also indicated that there will be a reduction of crop yields by as much as $50 \%$ by 2020 and crop revenues by $90 \%$ by 2100 respectively in some Africa countries with small-scale farmers suffering the most due to climate change (ibid). According to Dasgupta et al. (2009) there is generally an evidence that agriculture and water resource sectors, human health and livelihoods of women, children, the elderly and the disabled will be affected by climate change most especially the vulnerable. Land clearing is the second largest source of $\mathrm{CO}_{2}$ emissions after fossil-fuel combustion, accounting for $10-30 \%$ of net global $\mathrm{CO}_{2}$ emission (Rosenzweig and Hillel, 1998).

Forest stores about 20-40 times carbon per unit area than most crops and most of the carbon is released into the atmosphere through deforestation. Carbon loss from conversion of terrestrial ecosystems to agriculture is said to range from 21 to $46 \%$ (Schlesinger, 1986). Forest with vegetation cover is said to play a key role in mitigating climate change and variability by reducing temperature especially in the tropics. Bounoua et al. (2000) has observed a year round cooling of $0.8^{\circ} \mathrm{C}$ in the tropical areas of Africa due to increased vegetation cover. This therefore confirms the notion that the forest being a major carbon sink could help mitigate the effect of climate change. However, indiscriminate felling of trees without replacement, uncontrolled clearing of land for agriculture, bush burning are practices that affect the stability of the climate. Many researchers have confirmed that deforestation, land use and land use cover change play a key role in climate change and variability especially in areas noted for drought such as the Sahel and its immediate surroundings (Prospero and Lamb, 2003; Zeng,2003). The above research findings therefore call for the need to consider mitigation measures to reduce GHGs through proper land use and agricultural practices, efficient energy use, and frantic effort to prevent deforestation and land degradation.

The prediction of an increased in climate related natural disaster occurrence in response to change in the climate system is now well established (Maraseni, 2009; Rosenzweig, 2007; Sanders, 2010). The rising natural disasters affect the economy of many countries especially developing countries leaving millions in abject poverty and suffering. Economic losses from weather related natural hazards are rising, averaging roughly US\$100 billion per annum in the past decade (MunichRe, 2007). Climate change may also lead to migration of those who cannot really adapt to the impacts and this will results in people living their countries to become climate change refugees in other countries. It is estimated that 50-350 million people will become refugees by 2050 due to climate change and environmental degradation (UN, 2009). By 2020, the coastline between Accra (Ghana) and the Niger Delta (Nigeria) is predicted to become urban "megalopolis" of more than 50 million people (ibid). The challenge of sea level rise will affect these densely populated areas of the coast. Climate Change will bring about rainfall variability and increased temperature which will affect not only food production, but water quality, health, the economy and the social welfare of the people. Higher temperatures have also been linked to lower productivity Ebi et al. (2005) and may cause many organizations to spend a lot of money to install air-conditioners in offices especially tropical regions thus increasing the demand for energy which is already a problem for many African countries.

\section{Methodology}

This review was carried out to raise possible questions and discussions on the need to incorporate climate change issues into EIA processes. The research was carried out by an extensive review of literature, reports, interaction with opinion leaders, lecturers, colleagues and students. The interactions brought about various ideas and diversified opinions which were incorporated into this reviewed paper. The discussion is still ongoing and this paper therefore wishes to establish a chain of further discussions among politicians, opinion leaders, stakeholders and all environmental activists as to the best way to ensure environmental sustainability and climate change mitigation using EIA.

\subsection{Role of EIA in Mitigating Climate Change}

Every project no matter how small or large has both beneficial and adverse effects but the essence of EIA is to minimize the adverse effect on the environment or sort for an alternative approach to that project. The first step of the EIA process is to carry out screening to come out with an initial environmental examination or evaluation. This will determine whether EIA is required and if so then a scoping is done to identify the impacts and possible mitigations. The scoping will consider and gather critical impacts, involve the public and get their concerns, evaluate and prioritize impact issues, and develop a strategy to address them. The actual process of EIA procedure in Ghana is outlined in figure 1.

Following the EIA steps, it enables every undertaken to be properly examined before its inception to prevent any negative impact on the environment. Every undertaken that has the potential to emit GHGs, at least, should be taken through screening to ensure that the proponent carry out the right steps to mitigate environmental impact and make the project climate resilient. For instance, large scale land clearing for farming, logging of timber, small scale mining, sand winning or any undertaken that has to do with clearing of vegetation cover or emission of carbon must receive an environmental permit from EPA and this will make people conscious of the need to preserve the environment, reduce carbon emission and ensure sustainable development. 
Vehicles should also be regularly assessed for carbon emissions and beyond certain threshold a monthly or annual fine is imposed on the vehicle. All vehicles undergoing road worthiness must also be subjected to emission testing. Emission testing must also be extended to factories and manufacturing companies. The tax component of factories with high emissions should be higher than those with low emissions. Organisations or individuals with proper and workable environmental management systems should be given tax holidays or subsidies in the case of farmers.

In this case all the district assemblies should have EPA staff whose responsibility is to educate proponents on their responsibility and enforce the EIA regulations. If this is properly adopted and incorporated into developmental agenda of the nation, the commitment to keep $\mathrm{CO}_{2}$ emission below $2{ }^{\circ} \mathrm{C}$ will be a reality and the threat of climate change minimized. The nation can save a lot of money should this approach be adopted. An address read on behalf of President John D. Mahama during the fifth Annual Environmental and Natural Resources Summit at Sunyani revealed that environmental degradation through forest depletion, agricultural soil degradation and environmental health damage in Ghana by 2010 was said to have cost $3.7 \%$ of Gross Domestic Product (GDP). He said the cost of environmental degradation and the effect on climate change had worsened poverty levels in the country (GNA, 2012). The use of EIA to regulate activities that impact negatively on the environment cannot therefore be overemphasized.

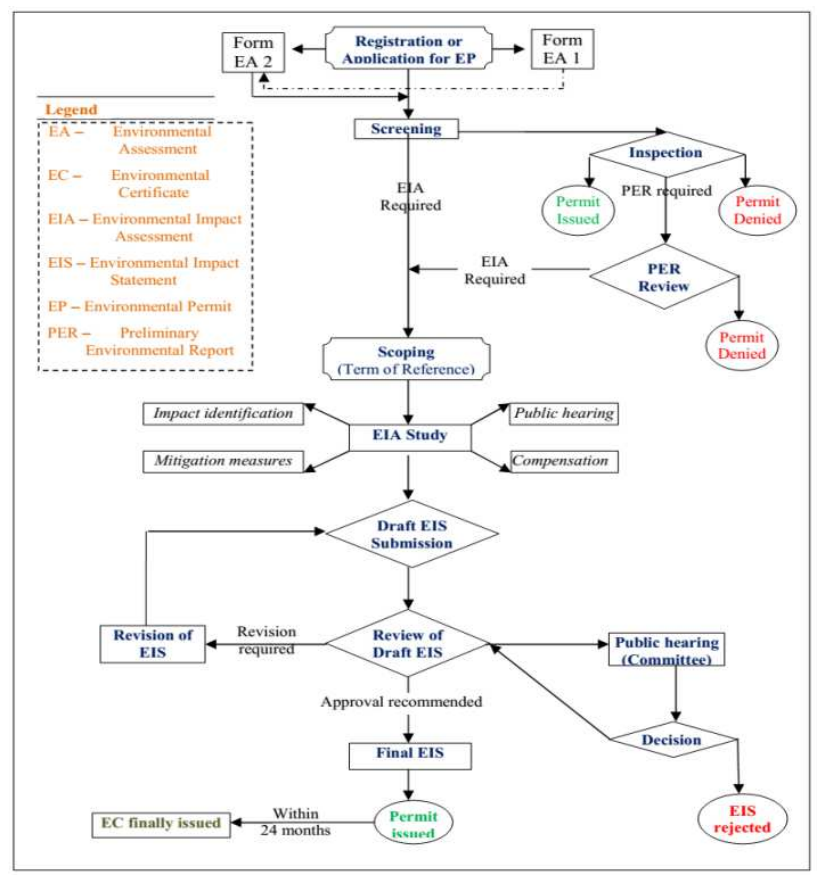

Figure 1. EIA procedure in Ghana, after EIA regulations, 1999

In Ghana the body responsible for ensuring the implementation of EIA is the Environmental Protection Agency (EPA) which was established in December 1994 to replace the then Environmental Protection Councils whose mandate was to advice, coordinate, investigate and educate people on all environmental issues. The functions of EPA are set out in the Environmental Protection Agency (EPA) Act 1994 (Act 490) which mandates the EPA, inter alia, to seek and request information on any undertaking that in the opinion of the Agency can have adverse environmental effects and to instruct the proponent to take measures to prevent any adverse impacts. Schedule 1 of the EIA regulation which was legislated in June 1999 through LI 1652 requires all undertaking with potential impact on the environment to register, submit EIA and receive approval and permit before commencement of the intended project. The four main steps used by EPA to conduct EIA in Ghana are: Project Registration, Screening, Scoping and Environmental Impact Statement (figure 1). In addition, the proponent is expected to submit an environmental management plan to EPA regularly throughout the lifespan of the project.

\section{Summary and the Way Forward}

The application of Environmental Impact Assessment in addressing the environmental challenges in Ghana is very paramount due to the numerous environmental challenges the country faces. The nexus between development and the environment, and the call for sustainable development has been a matter of concern to many developing countries especially with the emergence of climate change and its perceived impact. Many projects, even though very small may have some adverse effect on the environment thus the use of EIA instrument to regulate and monitor all projects will, unequivocally, reduce the environmental impact of such projects especially project that emit $\mathrm{CO}_{2}$ which is the most challenging GHG that needs to be dealt with to avert global catastrophe (Perlmutter and Rothstein, 2011). It has already been established that anthropogenic activities has been responsible for the changing climate (Prentice, 2001; IPPC, 2001; Zhang, 2007) thus when such activities are controlled and monitored, the threat of climate change could be reduced drastically.

The forest also plays an important role in climate change mitigation by removing $\mathrm{CO}_{2}$ from the atmosphere for storage (Schlesinger, 1986; Winrock, 2002; Hardy, 2005). However, deforestation and agricultural land clearing, poor agricultural practices such as slush and burn, uncontrolled use of fertilizers and pesticides will reduce the sequestration of $\mathrm{CO}_{2}$ and facilitate the process of climate change (Houghton, 1990; Rosenzweig, 2007; FAO, 2012). Monitoring and regulation of the forest and agricultural activities using the principle of EIA will therefore be in the right direction. It is important that any activity that has the potential of affecting the environment must be issued with environmental permit before it is initiated.

In recent times there has been increased importation of second hand cars to Ghana which requires regular checks because of the possible emissions. Even though there is a 
restriction in the importation of used vehicles aged beyond 10 years as a measure to reduce the emission of GHGs into the atmosphere, some of the vehicles within the 10 years are likely to emit emissions than vehicles beyond 10 years of age. It is therefore necessary for all second hand vehicles to undergo emission testing annually and be issued with environmental stickers. Vehicles that emit beyond certain thresholds are made to pay a specific fine monthly or annually as carbon tax. The use of fossil fuels and deforestation has been identified as the two main human activities that contribute enormously to climate change. EIA application must therefore be extended to these two major activities. The burning of oil, natural gas, and coal provides $80 \%$ of the world's commercial energy and this also cause $80 \%$ of all human-induced carbon dioxide emissions (Enger and Smith, 2008). Deforestation is also estimated to contribute $17.4 \%$ of anthropogenic GHG emissions, while transportation accounts for only $13.1 \%$ (IPPC, 2007).

The development of the National Climate Change Policy Framework (NCCPF) in Ghana is to ensure climate resilient and compatibility through sustainable economic development. The three main objectives of the NCCPF are to ensure low carbon emissions and growth, effective adaptation to climate change and socio-economic development. This basically confirms that the use of EIA to control deforestation and fossil fuels application will be one of the best ways in addressing climate change. However, the extension of EIA to regulate farming activities, transportation and other smaller projects must bring on board the leaders of the affected sectors. In an attempt to address climate change, there is the need to include indigenous knowledge through the involvement of the local people and community based leaders which the main stream of EIA has already taken into cognizance. According to Twinomugisha (2005) local farmers work with experience since they have been in the farming business for a long time thus the need to involve them in all climate change issues as failure to do so may bring various challenges. Unfortunately, this indigenous knowledge in climate variability is more often than not ignored in climate change studies (Nyong et al, 2007; Salick, 2009). According to Gbetibouo (2009) and Mertz et al. (2009) perceptions, experiences and indigenous knowledge of different farmers with different characteristics are very important in ensuring proper adaptation to climate change.

Beg et al. (2002) argued that even though most African countries have participate in international protocols and conventions to adopt sustainable and resource management, yet their policies do not fully embrace the issues of climate change. Such policies face a lot of challenges most especially the financial support to implement them. This nevertheless requires the international donor communities to increase support for adaptation, mitigation and disaster management especially in Africa (Huq, 2006).

The Amendment of the Environmental Assessment Regulations (EAR), 2002, LI 1703 clearly establishes charges to be taken by EPA for review and issuance of environmental permit and this will help generate additional funds for the agency to manage the environment when EIA is integrated into climate change mitigation or adaptation efforts. There have been many studies and proposals for the integration of EIA into a changing climate. The following websites provide information on the possible integration of EIA and climate change issues: www.iema.net/eia-climatechange; ec.europa.eu/environment/eia; www.fao.org.

Already, the concept of EIA has been accepted especially in Ghana and it will therefore not be difficult extending it to waste management, forestry, agriculture, transport, small scale mining, domestic and industrial projects. Any undertaking with adverse effect on the environment must go for permit from EPA which must be renewable as this will make proponents accountable. However, this new regulations should be preceded by vigorous public education, improvement of the lives of those who depend on the forest resources for their livelihood, enforcement of the basic laws of the land and political commitment. According to Karamouz et al. (2013) many UN conferences focus on population, food, women's rights, desertification and human settlement, and put continued emphasis on environmental issues. Ghana cannot therefore be left out in this global era of environmental sustainability.

\section{Conclusion}

This paper has attempted to justify the use of EIA in addressing the numerous environmental challenges confronting the country today by explaining the effect of climate change, outlining the process of EIA in Ghana. It is now clear that the principle of EIA could possibly be used to regulate many environmental challenges such as pollution abatement, waste management, conservation of natural resources, proper agricultural practices, development of clean energy sources, development of more energy efficient power sources and thus safeguarding the environment and improve the standard of living of Ghanaian . However, the proposed use of EIA to regulate any undertaking should not rather be used to, inter alia, frustrate, intimidate and discourage people from undertaken activities or projects that will improve the lives of the people through cumbersome and bureaucratic procedures. The procedure must be simple and straight forward which must be preceded by intensive public education, debates over the new policy and media engagement. Already it has been established that human induced activities have been responsible for the global carbon emissions thus the use of the principle of EIA to regulate $\mathrm{CO}_{2}$ emissions and other GHGs will be a step in the right direction. Institutional support, political commitment and the willingness to ensure sustainable and sound environmental practices must be the guiding principle for this proposal. The tragedy of the commons where people use resources anyhow because there is no regulation has resulted in the degradation of the environment in many countries and this must stop. Now, 
let's set the debate and discussions rolling to save the environment from climate change for posterity.

\section{References}

[1] Agyepong GT, Duadze SEK, Annor J, Donyuo SSB, Tetteh, E and Gyeabour, A (1999) Land use and land cover map of Ghana. Technical Bulletin. No. No. 3. Remote Sensing Applications, Unit, Dept. of Geography. University of Ghana, Legon, Accra.

[2] Anim-Kwapong GJ, and Frimpong EB (2006) Vulnerablity of agriculture to climate- impact of change change on cocoa production: Vulnerability and Adaptation Assessment under the Netherlands Climate Change Studies Assistance Programme Phase 2 (NCCSAP2). CRIG. New Tafo.

[3] Appiah-Opoku S (2001) Environmental impact assess ment in developing countries: the case of Ghana. Environmental Impact Assessment Review, Vol (21).1, 59-71

[4] Beg N, Morlot JC, Davidson et al. (2002) Linkages between climate change and sustainable development. Climate Policy 2: $129-144$

[5] Boko M, Niang I, Nyong A et al. (2007) Africa. Climate Change 2007: Impacts, Adaptation and Vulnerability. Contribution of Working Group II to the Fourth Assessment Report of the Intergovernmental Panel on Climate Change, M.L. Parry, O.F. Canziani, J.P. Palutikof, P.J. van der Linden and C.E. Hanson, Eds., Cambridge University Press, Cambridge UK, 433-467.

[6] Bounoua L, Collatz GJ, Los SO et al. (2000) Sensitivity of climate to changes in NDVI. J. Climate 13: 2277-2292

[7] Dasgupta S, Laplante D, Murray S and Wheeler D (2009) Sea-Level Rise and Storm Surges. A ComparativeAnalysis of Impacts in Developing Countries, Policy Reearch Working Paper 4901, DRG, Environment and Eergy Team, The World Bank

[8] Deressa TT, Hassan RM, Ringler C, Alemu T, and Yesuf M (2008) Analysis of the Determinants of Farmers' choice of Adaptation Methods and Perceptions of Climate Change in the Nile Basin of Ethiopia. International Food Policy Research Institute. Washington, DC

[9] Ebi KL, Smith JB and Burton I (2005) Integration of Public Health with Adaptation to Climate Change. New York: Taylor and Francis

[10] Enger DE and Smith FB (2008) Environmental Science: A Study of Interrelationships. 11th Edn., McGraw Hill, USA

[11] FAO 2010. Global Forest Land -Use Change 1990-2005. http://www.fao.org/docrep $/ 017 \quad$ /i3110e/i3110e.pdf (as sessed on 19/11/12)

[12] FES (2012). Climate Change and its impact on the livelihood of farmers and agricultural workers in Ghana. www.fesghana.org/uploads/PDF/Study_Climatechangeliveli hood.FINAL.pdf

[13] Gbetibouo GA (2009) Understanding farmers' perceptions and adaptations to climate change and variability. The case of the Limpopo basin, South Africa. Environment and Production
[14] Hardy JH (2005) Climate Change: Causes, Effects and Solutions. Wiley, England.

[15] Houghton RA (1990) The global effects of tropical deforestation. Environmental Science and Technology 24: $414-422$

[16] Huq S, Reid H and Murray LA (2006) Climate Change and Development Links. Gatekeeper Series 123, International Institute for Environment and Development.

[17] IPCC (2001) Climate Change (2001) The Scientific Basis. Contribution of Working Group I to the Third Assessment Report of the Intergovernmental Panel on Climate Change, J.T. Houghton, Y. Ding, D.J. Griggs, M. Noguer, P.J. vander Linden, X. Dai, K. Maskell and C.A. Johnson, Eds., CambridgeUniversity Press, Cambridge

[18] IPCC (2007) Summary for Policymakers. Climate Change 2007: The Physical Science Basis. Contribution of Working Group I to the Fourth Assessment Report of the Intergovernmental Panel on Climate Change, S. Solomon, D. Qin, M. Manning, Z. Chen, M. Marquis, K.B. Averyt, M. Tignor and H.L. Miller, Eds., Cambridge University Press, Cambridge. London

[19] Karamouz M, Nazif S and Falahi M (2013) Hydrology and Hydroclimatology: Principles and Applications. CRC Press. US.

[20] Maraseni TN, Maroulis J, Cockfield G, (2009) An analysis of Australia's carbon pollution reduction scheme. Int. J. Environ. Stud. 66 (5), 591-603

[21] Mertz O, Mbow C, Reenberg A, Diouf A (2009) Farmers' perceptions of climate change and agricultural adaptation strategies in Rural Sahel. Environ Manage 43:804-816

[22] MunichRe (2007) Natural Disasters. Annual Review of Natural Disasters 2006. Munich: Munich Reinsurance Group. Panel on Climate Change, M.L. Parry, O.F. Canziani, J.P. Palutikof, P.J. van der Linden and C.E. Hanson, Eds., Cambridge University Press, Cambridge, UK

[23] Nyong A, Adesina F, Osman EB (2007) The value of indigenous knowledge in climate change mitigation and adaptation variability and strategies in the African Sahel. Mitig Adapt Strat Glob Change 12:787-797

[24] Perlmutter DD and Rothstein LR (2011) The Challenges of Climate Change: Which way now? Wiley-Blackwell, UK.

[25] Prentice IC, Farquhar GD, Fasham et al. (2001) The carbon cycle and atmospheric carbon dioxide content. In Contribution of Working Group 1 to the 3rd Assessment Report of the IPPC, (eds). J. T. Houghton, Y. Ding D.J. Griggs, M. Noguer, P. J. van der Linden and D. Xiaosu. Cambrigde, UK and NY. pp 184-238

[26] Prospero JM and Lamb PJ (2003) African droughts and dust transport to the Caribbean: climate change implications. Science, 302, 1024-1027.

[27] Rosenzweig C, Casassa G, Karoly et al. (2007) Assessment of observed changes and responses in natural and managed systems. Climate Change 2007. Impacts, Adaptation and Vulnerability. Contribution of Working Group 11 to the Fourth Assessment Report of the IPCC, eds. M. L. Parry, O. F. Canziani, J. P. Palutikof, P.J. van der Linden and C.E. Hanson. Cambridge, UK and New York, NY: Cambridge University Press. pp 79-131 
[28] Rosenzweig CR and Hillel D (1998). Climate Change and the Global Harvest: Potential Impacts of the Greenhouse Effect on Agriculture. Oxford, Oxford University Press

[29] Salick J (2009) Traditional peoples and climate change. Glob Environ Change 19:37-139

[30] Sanders O, Goesch T, Hughes N (2010) Adapting to Water Scarcity. ABARE Issues and Insights 10.5, Australian Bureau of Agricultural and Resource Economics, Canberra, $\mathrm{ACT}$

[31] Schlesinger WH (1986) Changes in soil carbon storage and associated properties with disturbance and recovery. In: Trabalka J. R. and Reichle D.E. (Eds). The Changing Carbon Cycle: A global Analysis. Springer-Verlag, NY. pp. 194-220

[32] Twinomugisha B (2005) Indigenous adaptation. Tiempo 57 : 6-8
[33] UN General Assembly, Climate Change and its possible security implications : report of the Secretary-General, 11 September 2009, A/64/350, available at : http://www.refworld.org/ docid/4ad5e6380.html (accessed on $10 / 6 / 13)$.

[34] Winrock (2002) What You Should Know about Global Warming and Carbon Storage? http://www.winrock.org/GENERAL/Publications/ CarbonStorage.pdf ((assessed on 28/3/12)

[35] World Bank (2012) Turn Down the Heat: Why a $4^{\circ} \mathrm{C}$ Warmer World Must be Avoided. A Report for the World Bank by the Potsdam Institute for Climate Impact Research and Climate Analytics

[36] Zeng N (2003) Drought in the Sahel. Science 302: 999-1000

[37] Zhang X, Zwiers FW, Hegerl GC et al. (2007) Detection of human influence on twentieth-century precipitation trends. Nature 448: 461-65 